\title{
ANALISIS SUMBER DAN PENGGUNAAN MODAL KERJA PADA LEMBAGA PERKREDITAN DESA (LPD) DESA PAKRAMAN POH BERGONG PERIODE 2014-2016
}

\author{
Ni Kadek Candra Wahyuningsih \\ Jurusan Akuntansi Program Diploma III, \\ Universitas Pendidikan Ganesha, Singaraja \\ e-mail : candranikadek11@gmail.com
}

\begin{abstract}
Abstrak
Penelitian bertujuan untuk mengetahui analisis sumber dan penggunaan modal kerja pada Lembaga Perkreditan Desa (LPD) Desa Pakraman Poh Bergong periode 2014-2016.

Penelitian ini merupakan penelitian deskriptif kuantitatif. Subyek dari penelitian ini adalah Lembaga Perkreditan Desa (LPD) Desa Pakraman Poh Bergong. Obyek penelitian ini adalah analisis sumber dan penggunaan modal kerja pada Lembaga Perkreditan Desa (LPD) Desa Pakraman Poh Bergong periode 2014-2016. Jenis data yang digunakan adalah data kuantitatif. Sumber data yang digunakan adalah data sekunder. Metode pengumpulan data pada penelitian ini adalah (1) dokumentasi, (2) wawancara. Analisis data yang digunakan adalah analisis deskriptif kuantitatif.
\end{abstract}

Penelitian menunjukkan periode 2014-2015 terjadi kenaikan modal kerja sebesar Rp. 240.742.334,00 atau sebesar 36,07\%, periode 2015-2016 mengalami kenaikan modal kerja sebesar Rp. 226.356.389,00 atau sebesar 24,93\%. Sumber modal kerja Lembaga Perkreditan Desa (LPD) periode 2014-2015 dan periode 2015-2016 sebagian besar berasal dari cadangan umum. Alokasi penggunaan modal kerja periode 2014-2015 sebagian besar berasal dari akumulasi penyusutan.

Kata-kata kunci : Analisis, Sumber Modal Kerja, Penggunaan Modal Kerja, Lembaga Perkreditan Desa (LPD)

\begin{abstract}
This study aims to determine the analysis of sources and use of working capital at Village Credit Institution (LPD) Desa Pakraman Poh Bergong period 2014-2016.

This research is a quantitative descriptive research. The subject of this research is Village Credit Institution (LPD) Desa Pakraman Poh Bergong. The object of this research is the analysis of source and utilization of working capital at Lembaga Perkreditan Desa (LPD) Desa Pakraman Poh Bergong period 2014-2016. The type of data used is quantitative data. The data source used is secondary data. Methods of data collection in this study were (1) documentation, (2) interview. Data analysis used is quantitative descriptive analysis.

The results of this study indicate that from the period 2014-2015 there is an increase in working capital of Rp. $240,742,334.00$ or $36.07 \%$, the period $2015-2016$ experienced an increase in working capital of Rp. 226.356.389,00 or equal to 24,93\%. The source of working capital of Lembaga Perkreditan Desa (LPD) for the period 2014-2015 and the period 2015-2016 largely comes from general reserves. The allocation of working capital for the period 2014-2015 largely comes from accumulated depreciation.
\end{abstract}

Keywords: Analysis, Source of Working Capital, Use of Working Capital, Village Credit Institution $(L P D)$ 


\section{Pendahuluan}

Modal kerja merupakan hal yang penting dalam perusahaan hingga bisa dikatakan sebagai nyawa dari sebuah perusahaan artinya untuk menjalankan kegiatan operasinya sehari-hari ataupun untuk mengadakan investasi diperlukan modal kerja yang cukup. Untuk memperoleh modal kerja, pihak perusahaan harus memperhatikan setiap potensi keuangan yang ada dan bisa digunakan dengan memperhatikan segala kemungkinan risiko yang ditimbulkan. Mengingat begitu pentingnya peran modal kerja didalam sebuah perusahaan perlu dilakukan analisis terhadap sumber dan penggunaan modal kerja agar tidak terjadi penyalahgunaan yang dapat merugikan perusahaan.

Pemerintah Propinsi Bali mengeluarkan Peraturan Daerah Nomor 2 Tahun 1988 yang dijadikan dasar hukum dalam mendirikan sebuah lembaga yang berada di Tingkat desa yang dimiliki desa adat yang bergerak dalam bidang simpan pinjam disebut dengan Lembaga Prekreditan Desa (LPD). Maksud dan tujuan berdirinya Lembaga Perkreditan Desa digunakan menjaga pembangunan desa adat, memeratakan perekonomian di desa adat dan membuka lapangan kerja. Agar hal tersebut dapat tercapai, maka Lembaga Perkreditan Desa (LPD) sebagai suatu organisasi ekonomi dan kegiatan usaha ini memerlukan modal yang cukup, yang akan digunakan untuk membelanjai operasinya sehari-sehari kerja. Sebagai sebuah desa yang bersifat administratif, mempunyai sifat otonomi dan memiliki kesatuan hukum asli dengan sebutan Desa Adat.

LPD sebagai salah satu badan usaha senantiasa harus diarahkan dan di dorong untuk ikut berperan secara nyata meningkatkan pendapatan dan kesejahteraan, agar mampu mengatasi ketimpangan ekonomi dan mampu berperan sebagai wadah kegiatan ekonomi rakyat.

Sumber-sumber modal kerja perusahaan diperoleh dari kegiatan atau aktifitas perusahaan yang menyebabkan terjadinya perubahan-perubahan dari unsur-unsur aktiva tetap, utang jangka panjang dan modal sendiri yang dapat memperbesar modal kerja merupakan sumber modal kerja. Sebaliknya perubahan-perubahan dari aktiva tetap, utang jangka panjang dan modal sendiri yang memperkecil modal kerja merupakan penggunaan modal kerja perusahaan. Sumber modal lebih besar dari penggunaan, berarti ada kenaikan modal kerja, sebaliknya apabila penggunaan lebih besar dari pada sumber, berarti terjadi penurunan modal kerja.

A.A Ngr Rendy Pranata (2015) mengatakan bahwa, "analisis sumber dan penggunaan modal kerja diperlukan untuk mengetahui keefektifan dan kinerja, baik itu dilihat dari sumber dan penggunaan modal kerja". Selain itu dengan adanya analisis sumber dan penggunaan modal kerja akan dapat lebih baik dalam mengelola keuangannya untuk tetap menjadikan LPD Desa Poh Bergong dengan aset terbesar. Maka dari itu, penulis tertarik melakukan penelitian dengan judul "Analisis Sumber dan Penggunaan Modal Kerja pada Lembaga Perkreditan Desa (LPD) Desa Pakraman Poh Bergong Periode 20142016".

\section{Metode Penelitian}

Rancangan Penelitian merupakan suatu kesatuan dari sebuah rencana yang rinci dan spesifik mengenai cara untuk memperoleh, menganalisis dan menginterprestasi suatu data. Rancangan penelitian dipergunakan sebagai dasar untuk melakukan penelitian. Tujuan dari diadakannya penelitian ini adalah untuk memperoleh informasi sesuai dengan penelitian yakni analisis sumber dan penggunaan modal kerja pada Lembaga Perkreditan Desa (LPD) Desa Pakraman Poh Bergong periode 2014-2016. Adapun sistematika yang dilakukan adalah dimulai dari observasi awal pada lokasi penelitian yaitu Lembaga Perkreditan Desa (LPD) Desa Pakraman Poh Bergong untuk mendapatkan gambaran mengenai kegiatan operasional Lembaga Perkreditan Desa yang bersangkutan. Dari proses observasi awal tersebut maka ditetapkan rumusan masalah, kemudian untuk menjawab rumusan masalah yang telah dibuat tersebut, maka akan dicari kajian teori yang sesuai dengan masalah yang diangkat. Setelah kajian teori ditemukan, maka dilakukan 
pengumpulan data sekunder. Metode yang digunakan dalam proses pengumpulan data yaitu dengan menggunakan metode wawancara dan metode dokumentasi. Setelah pengumpulan data selesai dan data-data yang dikumpulkan sudah lengkap, maka tahap berikutnya adalah mengolah data. Setelah data diolah dan dianalisis dengan menggunakan analisis deskriptif kuantitatif dan analisis yang digunakan adalah analisis horisontal atau yang sering disebut dengan analisis dinamis, yang membandingkan laporan keuangan lebih dari satu periode yaitu dari tahun 2014, 2015 dan 2016.

\section{Hasil dan Pembahasan}

Berdasarkan Laporan Perubahan Modal Kerja periode 2014-2015 diketahui jumlah kenaikan modal kerja periode 2014-2015 yaitu sebesar Rp 240.742.334,00 atau 36,07 \%. Perubahan-perubahan unsur-unsur dari modal kerja yaitu :

1. Kas mengalami peningkatan sebesar $\mathrm{Rp} 110.287 .400,00$ atau sebesar $58,24 \%$ dari tahun sebelumnya.

2. Tabungan Giro mengalami penurunan sebesar Rp 6.264.251,00 atau sebesar $100 \%$ dari tahun sebelumnya.

3. Tabungan BPD mengalami peningkatan sebesar Rp 142.648.191,00 atau sebesar $20,32 \%$ dari tahun sebelumnya.

4. Deposito BPD tidak mengalami peningkatan ataupun penurunan dari tahun sebelumnya.

5. Pinjaman Bulanan mengalami peningkatan sebesar Rp 400.234.300,00 atau sebesar $11,51 \%$ dari tahun sebelumnya.

6. Tabungan Wajib Pinjaman mengalami peningkatan sebesar Rp 7.497.800,00 atau sebesar $8,41 \%$ dari tahun sebelumnya.

7. Tabungan Sukarela mengalami peningkatan sebesar $\mathrm{Rp} 244.701 .506,00$ atau sebesar $8,70 \%$ dari tahun sebelumnya.

8. Simpanan Berjangka mengalami peningkatan sebesar Rp 152.500.000,00 atau sebesar $18,75 \%$ dari tahun sebelumnya.

9. Pinjaman Luar mengalami penurunan sebesar Rp 1.250.000,00 atau sebesar $100 \%$ dari tahun sebelumnya.

10. Kewajiban Lain-Lain mengalami peningkatan sebesar Rp 2.754.000,00 atau sebesar $98,32 \%$ dari tahun sebelumnya.

Berdasarkan Laporan Perubahan Modal Kerja periode 2015-2016 diketahui jumlah kenaikan modal kerja periode 2015-2016 yaitu sebesar Rp 226.356.389,00 atau 24,93\%. Perubahan-perubahan unsur-unsur dari modal kerja yaitu :

1. Kas mengalami penurunan sebesar $\mathrm{Rp} 192.713 .700,00$ atau sebesar $64,31 \%$ dari tahun sebelumnya.

2. Tabungan BPD mengalami penurunan sebesar $\mathrm{Rp} 56.445 .911,00$ atau sebesar 6,68 $\%$ dari tahun sebelumnya.

3. Deposito BPD mengalami peningkatan sebesar Rp 500.000.000,00 atau sebesar $5.000 \%$ dari tahun sebelumnya.

4. Pinjaman Bulanan mengalami peningkatan sebesar Rp 518.985.600,00 atau sebesar $13,38 \%$ dari tahun sebelumnya.

5. Tabungan Wajib Pinjaman mengalami peningkatan sebesar Rp $12.325 .800,00$ atau sebesar $12,76 \%$ dari tahun sebelumnya.

6. Tabungan Sukarela mengalami peningkatan sebesar $\mathrm{Rp} 305.461 .800,00$ atau sebesar 9,99\% dari tahun sebelumnya.

7. Simpanan Berjangka mengalami peningkatan sebesar $\mathrm{Rp} 219.000 .000,00$ atau sebesar $22,67 \%$ dari tahun sebelumnya. 
8. Kewajiban Lain-Lain mengalami peningkatan sebesar Rp 6.682.000,00 atau sebesar $120,29 \%$ dari tahun sebelumnya.

Dari laporan sumber dan penggunaan modal kerja dapat diketahui jumlah sumber modal kerja, penggunaan modal kerja serta kenaikan modal kerja selama periode 20142015. Pada periode 2014-2015 Lembaga Perkredita Desa (LPD) Desa Pakraman Poh Bergong mengalami kenaikan modal kerja sebesar Rp 240.742.334,00. Hal ini disebabkan karena jumlah modal kerja lebih besar dari jumlah penggunaan modal kerja pada periode tersebut. Sumber modal kerja sebesar Rp 248.237.199,00 sedangkan jumlah penggunaan modal kerja sebesar Rp 7.494.865,00.

Sumber-sumber modal kerja Lembaga Perkreditan Desa (LPD) Desa Pakraman Poh Bergong periode 2014-2015 berasal dari :

1. Bertambahnya Cadangan Pinjaman Ragu-Ragu

Cadangan Pinjaman Ragu-Ragu bertambah sebesar Rp 47.735.000,00 yaitu pada tahun 2014 sebesar $R p \quad 76.347 .000,00$ sedangkan tahun 2015 sebesar $R p$ $124.082 .000,00$

2. Berkurangnya Aktiva Lain-Lain

Aktiva Lain-Lain mengalami penurunan sebesar Rp $10.539 .577,00$ yaitu pada tahun 2014 sebesar Rp 21.082.000,00 sedangkan tahun 2015 sebesar Rp 10.542.423,00

3. Bertambahnya Cadangan Umum

Cadangan Umum mengalami peningkatan sebesar Rp 140.510.236,00 yaitu pada tahun 2014 sebesar Rp 492.041.058,00 sedangkan tahun 2015 sebesar Rp $632.551 .249,00$

4. Bertambahnya R/L Tahun Lalu

$\mathrm{R} / \mathrm{L}$ Tahun Lalu mengalami peningkatan sebesar $\mathrm{Rp} 49.452 .386,00$ yaitu pada tahun 2014 sebesar Rp 24.182.236,00 sedangkan pada tahun 2015 sebesar Rp 283.634.622,00.

Penggunaan Modal Kerja pada Lembaga Perkreditan Desa (LPD) Desa Pakraman Poh Bergong periode 2014-2015 sebagai berikut :

1. Berkurangnya Akumulasi Penyusutan

Berkurangnya Akumulasi Penyusutan dari tahun 2014-2015 sebesar Rp $6.244 .865,00$

2. Bertambahnya Harga Perolehan

Harga Perolehan mengalami peningkatan sebesar $\mathrm{Rp} 1.250 .000,00$ yaitu pada tahun 2014 sebesar Rp 185.324.350,00 sedangkan tahun 2015 sebesar Rp 186.574.350,00.

Dari laporan sumber dan penggunaan modal kerja dapat diketahui jumlah sumber modal kerja, penggunaan modal kerja serta kenaikan modal kerja selama periode 20152016. Pada periode 2015-2016 Lembaga Perkredita Desa (LPD) Desa Pakraman Poh Bergong mengalami kenaikan modal kerja sebesar Rp 226.356.389,00. Hal ini disebabkan karena tidak ada penggunaan modal kerja pada periode tersebut.

Sumber-sumber modal kerja Lembaga Perkreditan Desa (LPD) Desa Pakraman Poh Bergong periode 2015-2016 berasal dari :

1. Bertambahnya Cadangan Pinjaman Ragu-Ragu

Cadangan Pinjaman Ragu-Ragu bertambah sebesar Rp 34.342.000,00 yaitu pada tahun 2015 sebesar Rp 124.082.000,00 sedangkan tahun 2016 sebesar Rp $158.424 .000,00$

2. Berkurangnya Aktiva Lain-lain 
Aktiva Lain-Lain mengalami penurunan sebesar Rp 1.520.824,00 yaitu pada tahun 2015 sebesar Rp 10.542.423,00 sedangkan tahun 2016 sebesar Rp 9.021.599,00

3. Bertambahnya Cadangan Umum

Cadangan Umum mengalami peningkatan sebesar Rp 170.181.622,00 yaitu pada tahun 2015 sebesar Rp 632.551.249,00 sedangkan tahun 2016 sebesar Rp 802.732.916,00

4. Bertambahnya R/L Tahun Lalu

R/L Tahun Lalu mengalami peningkatan sebesar Rp 19.374.943,00 yaitu pada tahun 2015 sebesar $\mathrm{Rp}$ 283.634.622,00 sedangkan pada tahun 2016 sebesar $\mathrm{Rp}$ 303.009.565,00.

5. Bertambahnya Akumulasi Penyusutan

Berkurangnya Akumulasi Peningkatan dari tahun 2015-2016 sebesar Rp $937.000,00$

4. Simpulan dan Saran

Sumber modal kerja Lembaga Perkreditan Desa (LPD) periode 2014-2015 dan periode 2015-2016 sebagian besar berasal dari cadangan umum. Alokasi penggunaan modal kerja periode 2014-2015 sebagian besar berasal dari akumulasi penyusutan. Untuk LPD agar memperhatikan cadangan umum yang dimilikinya sehingga LPD dapat terus menjalankan aktivitas operasionalnya dan bagi penelitian selanjutnya dapat dilakukan uji hipotesis dan dapat dilaksanakan wawancara yang lebih mendalam sehingga dapat lebih jelas mengetahui alokasi sumber dan penggunaan dana di LPD.

\section{Daftar Pustaka}

Baridwan, Zaki.1992.Intermediate Accounting.Edisi 7.Yogyakarta:BPFE

Brigham, Houston, 2001. Akuntansi Keuangan Menengah. Edisi kesembilan, Jilid Satu, Terjemahan. Salemba Empat, Jakarta.

Ferdinnsyah.2007.Ekonomi untuk SMS dan MA kelas XII IPS. Jilid 3.Jakarta:Tropica

Harapan.2004.Analisis Kritis Atas Laporan Keuangan.Jakarta:PT.Raja Gradindo

Herawati, Trisna.2006.Pengantar Akuntansi 1.Undiksha Singaraja

Ikatan Akuntansi Indonesia. 2004.Standar Akuntansi Keuangan.Jakarta:Selemba Empat

Kasmir.2008.Analisis Laporan Keuangan.Jakarta:Rajawali Pers

LP LPD Provinsi Bali.2015.Standar Kerja Organisasi dan Manajemen SDM LPD $B A L I$. Provinsi Bali

Munawir,S.1995.Analisis Laporan Keuangan.Yogyakarta:Liberty

Pranata,Rendy, A.A Ngr.2015.Analisis Sumber dan Penggunaan Modal Kerja Pada Koperasi Pegawai Negeri (KPN) Mahayu Warga Periode 2012-2014.Undiksha

Prastowo, Dwi dan Rifka Juliati.2005. Analisis Laporan Keuangan, Konsep dan Aplikasi.Edisi Revisi.Yogyakarta:Unit Penerbit dan Persetakan Akademi Manajemen Perusahaan YKPN

Riyanto,Bambang.1995.Dasar-dasar

Pembelanjaan

Perusahaan.Edisi Empat.Yogyakarta:BPFE 
VOL.8 NO 1.APRIL 2019

p-ISSN:2337-537X: e-ISSN:

Soemarso.1999.Analisis Lapporan Keuangan.Jakarta:PT Bumi Aksara

Sugiyarso, Winarni.2005.Penyusunan \& Analisis Laporan Keuangan Pemerintah Daerah.Yogyakarta:Andi

Yusuf, AL Hariyono. 2005. Dasar-dasar Akuntansi.Yogyakarta: Liberty. 